\title{
Tetrazolium Vital Staining for Early Detection of Corneal Graft Rejection
}

\author{
Istiantoro Sukardi, dr; Tjahjono D Gondhowiardjo, dr; Bondan Harmani, dr.
}

\begin{abstract}
Abstrak
Secara klinis, sulit untuk menegakkan diagnosis adanya reaksi penolakan kornea dini dengan hanya menggunakan pemeriksaan lampu celah. Pada binatang percobaan telah dilaporkan kemungkinan kegunaan teknik pengecatan vital dengan menggunakan Iodo-nitro-tetrazolium (INT) untuk menegakkan adanya reaksi penolakan kornea dini. Penggunaan teknik pengecatan vital didasarkan pada adanya perubahan aktifitas enzim di dalam sel-sel yang sedang berdegenerasi. Meningkatnya aktifitas enzim-enzim dehidrogenase sel akan melepaskan ion hidrogen zat warna dan terjadi ikatan antara zat warna dengan struktur kimia sel dan menimbulkan perubahan warna yang dapat dinilai. Pada penelitian ini, didapatkan adanya hubungan searah antara penemuan klinis secara morfologik dengan hasil pengecatan vital, akan tetapi ternyata teknik pemeriksaan dengan zat warna ini tidak dapat dijadikan sebagai alat bantu penilaian jaringan kornea yang dicangkokkan. Hal ini disebabkan karena pengecatan vital INT hanya sensitif pada minggu pertama pasca bedah. Akan tetapi hasil ini tidaklah menutup kemungkinan penggunaan zat warna lain yang lebih peka terhadap perubahan enzim di dalam sel-sel yang sedang berdegenerasi.
\end{abstract}

\section{Abstracts}

Clinically, it is difficult to detect early graft rejection by slitlamp biomicroscopy. Previous animal experiments indicate that Iodo-nitro-tetrazolium (INT) vital staining may be useful in the diagnosis of an early corneal graft rejection. Vital staining techniques are based on enzymatic changes within the degenerating cells, the activated dehydrogenases of the degenerating cells will release the INT hydrogen ions and will result in a visible coloration. Our study revealed, that although INT vital staining showed a positive correlation with the clinical morphological finding, it could not be used as a diagnostic tool in evaluating a corneal graft condition since it is only sensitive in the first week post surgery. However, this result does not close the possibilities of using other vital dyes which might be more sensitive.

Keywords : Vital staining, lodo-nitro-tetrazolium, Corneal graft rejection.

\section{INTRODUCTION}

Biomicroscope examination is the main tool in establishing morphological changes in the diagnosis of corneal graft rejection. However, it is often found that although some patients present subjective complaints, no morphological changes can be detected clinically. Such a situation is critical and might lead into a lost of the corneal graft transparency. A corneal graft can become opaque in a short time due to tissue rejection reaction, especially in the first year after the transplantation. ${ }^{1}$
It is known that generally morphological changes in the corneal epithelium cells are preceded by some enzymatic changes within the cells. ${ }^{2}$ These enzymatic changes would result in changes of cell wall permeability which could be evaluated with the help of vital staining technique. Thus, in biomicroscopy vital staining might be of advantage in establishing the clinical diagnosis. $^{3}$

Vital staining is the staining of living cells, microorganism, or certain tissues in vivo, which enables us to differentiate them from other cells or tissues which do not have the ability to take the dye. , $^{3,5}$ 
Gondhowiardjo, ${ }^{6}$ on a rabbit model, using iodonitro-tetrazolium dye (INT) had proven the sensitiveness of this vital staining technique which resulted in a positive staining 4 to 8 days before any morphological changes could be seen in corneal graft rejection. The evaluation is based on enzymatic changes within cells, and the release of hydrogen ions from the clear INT solution, resulting in a visible coloration of the degenerating cells. ${ }^{4,5}$

In this study, we would like to evaluate the clinical benefits of INT vital staining for penetrating keratoplasty cases. The result indicate that although there was a positive correlation found between the vital staining finding and the clinical morphology, the INT dye could not be used as a diagnostic aid for corneal graft conditions. This is due to the fact that INT staining only give a positive result in the first week postsurgery.

\section{MATERIALS AND METHODS}

The study was performed prospectively on all patients who underwent penetrating keratoplasty in the Corneal clinic of the Department of Ophthalmology, University of Indonesia, Faculty of Medicine / Dr. Cipto Mangunkusumo Hospital, Jakarta. The findings of the INT dye were compared with the clinical morphology pictures of the corneal graft in two groups of patients. The first group had neovascularization more than one quadrant wide, while the second group, without neovascularization, was used as a control group.

All patients included in this study had been given ample explanation about the goals and objectives of this study, and had given written informed consent for the procedure. No differentiation was made on sex and age distribution. Postoperatively, all patients were treated with dexamethasone $0.1 \%$ eye drops (Cendo, Bandung, Indonesia) four times a day. The evaluation was performed with a biomicroscope once a week in the first month, every two weeks in the second month after the corneal transplantation, and in the event of corneal graft rejection. The examination for the vital staining was done four minutes after administration of a drop of $1 \%$ INT solution (Sigma, St. Louis, USA) into the operated eye. Positive staining could be demonstrated as multiple red dots, and each dot represented a degenerating cell. ${ }^{4}$

In each evaluation, any corneal transparency changes and signs of inflammation of the anterior segment of the eye were searched for, and intra ocular pressure readings were taken. The positive staining of the corneal epithelium cells was registered, especially if it is located on the periphery / border of the graft-host tissues. Any patient who did not follow the posttransplantation evaluation schedule was excluded from the significance analysis.

The levels of the clinical morphological changes of the corneal graft were evaluated with a "biomicroscopy scoring" presented in table 1 . Whereas, the results of INT staining were evaluated with "vital staining scoring" presented in table 2 . The data analysis was processed with the aid of a computer using student $t$ test and rank correlation test.

Table 1. Biomicroscopic Scoring

\begin{tabular}{|c|c|c|}
\hline & score \\
\hline \multicolumn{3}{|c|}{ 1. Epithelium defect } \\
\hline None & & 0 \\
\hline None - few & ( $<$ corneal diameter $)$ & 1 \\
\hline A few & (- corneal diameter) & 2 \\
\hline Moderate & (> corneal diameter) & 3 \\
\hline Large & (the entire corneal surface) & 4 \\
\hline \multicolumn{3}{|c|}{ 2. Stromal edema } \\
\hline \multicolumn{2}{|c|}{ None (iris crypts clearly seen) } & 0 \\
\hline \multicolumn{2}{|c|}{ None - semi transparent } & 1 \\
\hline \multicolumn{2}{|c|}{ Semitransparent (blurred iris crypts) } & 2 \\
\hline \multicolumn{2}{|c|}{ Semitransparent - opaque } & 3 \\
\hline \multicolumn{2}{|c|}{ Opaque (non visible anterior chamber) } & 4 \\
\hline \multicolumn{3}{|c|}{ 3. Descemet's folds } \\
\hline & & 0 \\
\hline \multicolumn{2}{|c|}{ None - a few } & 1 \\
\hline \multicolumn{2}{|c|}{ A Few (2-5 folds) } & 2 \\
\hline \multicolumn{2}{|c|}{ Moderate ( $>5$ folds) } & 3 \\
\hline \multicolumn{2}{|c|}{ Descemet plaque } & 4 \\
\hline
\end{tabular}

Table 2. INT vital staining scoring

\begin{tabular}{lll}
\hline & score \\
\hline No staining of corneal epithelium & 0 \\
Weak positive staining & $(<10$ cells $)$ & 1 \\
Moderate positive staining & $(10-20$ cells $)$ & 2 \\
Strong positive staining & $(>20$ cells $)$ & 3 \\
& & \\
\hline
\end{tabular}

\section{RESULTS}

This study was conducted on 43 patients who underwent penetrating keratoplasty and regular control for 2 months following surgery. There were 23 patients $(53.5 \%)$ in the group with neovascularization and 20 patients $(46.5 \%)$ in the group without neovascularization. 
After 8 weeks post-surgery, evaluation with the biomicroscopic and vital staining combination, it was found that no significant difference $(p=0.81)$ could be detected between the two groups (Table 3). Although the two techniques used (clinical biomicroscopy and the combination biomicroscopy with vital staining) had statistical correlation in evaluating the clear corneal graft without any complication (Table 4, $\mathrm{r}=0.842$ ), it was found that this combined evaluation did not run parallel with evident corneal graft failure (Table 5, $r=0.501$ ) which occured in seven of the patients.

Table 3. Average distribution of biomicroscopic and INT vital staining scoring in relation to time (week) and corneal condition (with or without neovascularization).

\begin{tabular}{|c|c|c|c|c|}
\hline \multirow{2}{*}{$\begin{array}{l}\text { Time } \\
\text { (week) }\end{array}$} & \multicolumn{2}{|c|}{ Neovascularization $(+)$} & \multicolumn{2}{|c|}{ Neovascularization (-) } \\
\hline & biomicr. & INT & biomicr. & INT \\
\hline 1 & 3.08 & 1.6 & 3.05 & 1.65 \\
\hline II & 1.26 & 0.82 & 1.15 & 0.6 \\
\hline III & 0.65 & 0.39 & 0.65 & 0.6 \\
\hline IV & 0.65 & 0.26 & 0.6 & 0.3 \\
\hline VI & 0.86 & 0.39 & 0.35 & 0.1 \\
\hline VIII & 0.91 & 0.43 & 0.4 & 0.1 \\
\hline
\end{tabular}

neovascularization (+)

neovascularization (-)

n:23

$\mathrm{n}: 20$

Table 4. Average distribution of biomicroscopic and INT vital staining in relation to time for uncomplicated corneal grafts.

\begin{tabular}{lll}
\hline $\begin{array}{c}\text { Time } \\
\text { (week) }\end{array}$ & Biomicroscopic & INT \\
\hline I & 2.92 & 1.34 \\
II & 0.80 & 0.42 \\
III & 0.23 & 0.03 \\
IV & 0 & 0 \\
VI & 0.07 & 0.07 \\
VIII & 0.07 & 0.07 \\
\hline
\end{tabular}

$\mathrm{n}: 26$

Table 5. Average distribution of biomicroscopic and INT vital staining in relation to time for corneal graft failure.

\begin{tabular}{lll}
\hline $\begin{array}{l}\text { Time } \\
\text { (week) }\end{array}$ & Biomicroscopic & INT \\
\hline I & 3.28 & 2 \\
II & 2.71 & 1.57 \\
III & 2.71 & 1.57 \\
IV & 3 & 1.42 \\
VI & 3.57 & 1.42 \\
VIII & 3.85 & 1.42 \\
\hline
\end{tabular}

\section{DISCUSSION}

It is known that corneal epithelium rejection, subepithelial (stromal) and endothelial rejection might occur in corneal graft reaction. Endothelium rejection can occur with stromal and epithelial rejection, and stromal rejection might be accompanied by epithelial rejection. ${ }^{7,8}$ Based on permeability changes in the corneal epithelium, we tried to use vital staining technique as a diagnostic aid for evaluating corneal graft conditions. Intracellular enzymatic changes which precede the morphologic changes in the cells, will impair the cell wall permeability allowing the dye to enter the cell. Then the activated dehydrogenase enzymes will release hydrogen ions from the dye's molecular structure giving rise to colour changes which can be evaluated. ${ }^{2,3,4,9}$

The biomicroscopy scoring system and the vital staining scoring were established to make an objective evaluation of the corneal graft morphologic condition. Evidence indicate, that the in-vivo corneal biomicroscopy scoring runs parallel with the score of whole-eye corneal donor which is still fit to be transplanted (score 4). ${ }^{10}$

In the first week of evaluation, the average biomicroscope score was 3 and decreased at the second week post surgery, in concordance to the disappearance of edema and improved metabolism in the corneal graft. However, this score did not have any meaning anymore because the score was less than one. Corneal grafts failure had a score between 2.7-3.8. Similar findings were found with vital staining scoring, in the first week weak stainings were obser-ved, and no more staining could be seen in the following weeks. This correlation was confirmed statistical-ly. Patients with graft failure on the average gave staining scores of 1.4-2 (medium staining). In fact, one (14.2\%) patient who had a graft rejection episode had a biomicroscopic score of 3 and a vital staining score of 2.5 .

Although both techniques of evaluation gave a correlation for clear graft, it was found that there was a disagreement between the two methods in evaluating graft failure with lost of corneal graft transparency. This might be due to the variations of the causes of the corneal graft failure, and not just a pure graft rejection. In addition, the samples might not be normally distributed due to the small number of the samples.

In a previous experiment with rabbit corneas, INT vital staining technique gave positive results preceding morphologic changes which later occurred because of graft rejection reaction. ${ }^{10}$ The differences might be due to the more intensive evaluation method (every 2 days), homogenous sample group and species differen- 
ces in the structure and metabolism of corneal epithelium. ${ }^{11}$

\section{CONCLUSION}

Since the INT vital staining was only found to be applicable in the first week of corneal graft transplantation and no correlation was found for corneal graft failure, this technique cannot be used as an objective criterion in evaluating corneal graft condition. However, this finding does not close the possibility of using other vital dyes which might be more sensitive, for in vivo evaluation of enzymatic changes in corneal graft failure.

\section{REFERENCES}

1. Casey TA, Mayer DJ. Corneal Grafting. Principles and practice. First edition. WB Saunders company, PhiladelphiaLondon - Toronto - Mexico City - Rio de Janeiro - Sidney Tokyo 1984.

2. Robbins SL, Cotran RS. Pathologic basis of disease. Second edition. Chapter. 2. Cell injury and cell death. W.B.Saunders Company. Philladelphia-London-Toronto. 1979; 22-54.
3. Passmore JW, King Jr JH. Vital staining of conjungtiva and cornea. Review of literature and clinical study of certain dyes. Arch Ophthalmol 1955;53: 568-74.

4. Norn MS. Iodonitrotetrazolium vital staining of cornea and conjungtiva. Acta Ophthalmol 1971;49:90-102.

5. Norn MS. Tetrazolium-Alcian Blue mixtures. I. Vital staining of cornea and conjungtiva. Acta Ophthalmol 1972;50:277-85.

6. Gondhowiardjo TD. Pengecatan vital pada reaksi penolakan kornea. Percobaan kelinci. Skripsi Bagian IImu Penyakit Mata FKUI/RSCM.

7. Alldredge C, Krachmer JH. Clinical types of corneal transplant rejection. Their manifestation, frequency. Preoperative correlates and treatment. Arch Ophthalmol 1981;99:599-604.

8. Khoudadoust AA, Silverstein AM. Transplantation and rejection of individual cell layers of the cornea. Invest. Ophthalmol 1969; $8: 180-95$.

9. Basu PK, Hasany SM. Histochemical localization of hydrolytic enzymes during corneal graft reaction. Canad J Ophthalmol 1975;10:239-47.

10. Gondhowiardjo TD, Bondan H, Istiantoro. Skoring biomikroskopik pada kornea donor 'Srilanka. Paper Bagian IImu Penyakit Mata FKUI/RSCM. Tidak dipublikasikan.

11. Ehlers N. Some comparative studies on the mammalian corneal epithelium. Acta Ophthalmol 1970;48:821-28. 